\title{
Where are we short and who are we short of? A review of the human resources for health in South Africa
}

\author{
Author: \\ Gavin George ${ }^{1}$ \\ Timothy Quinlan ${ }^{1}$ \\ Candice Reardon ${ }^{1}$ \\ Jean-François Aguilera² \\ Affiliations: \\ ${ }^{1}$ Health Economics and HIV \\ and AIDS Research Division \\ (HEARD), University of \\ KwaZulu-Natal, South Africa \\ ${ }^{2}$ European Commission \\ Delegations, in Southern \\ Africa

\section{Correspondence to:} \\ Gavin George \\ Email: \\ georgeg@ukzn.ac.za \\ Postal Address: \\ HEARD, 4th Floor J Block, \\ Westville Campus, Durban \\ 4041, South Africa \\ Dates: \\ Received: 19 Sept. 2011 \\ Accepted: 01 Oct. 2012 \\ Published: 11 Dec. 2012 \\ How to cite this article: \\ George, G., Quinlan T., \\ Reardon, C. \& Aguilera J-F., \\ 2012, 'Where are we short \\ and who are we short of? \\ A review of the Human \\ Resources for Health in \\ South Africa', Health SA \\ Gesondheid, 17(1), Art. \#622, \\ 7 pages. http://dx.doi.org/ \\ 10.4102/hsag.v17i1.622
}

(C) 2012. The Authors. Licensee: AOSIS OpenJournals. This work is licensed under the Creative Commons Attribution License.
This review showed that thinking about the shortage of health care personnel merely in terms of insufficient numbers prevents sound strategic interventions to solve the country's human resources for health (HRH) problem. It revealed that the numbers shortage was one facet of a broader problem that included the mal distribution of $\mathrm{HRH}$, production of the wrong skills in the nursing care, the attrition of staff from the public health services and, contextually, the ever-changing demands on the health services. The challenge in South Africa was furthermore to train and retain health care personnel with skills and expertise that are commensurate with the changing demands on the public health services.

Uit hierdie oorsig het dit duidelik geblyk dat die tekort van gesondheidsorgpersoneel slegs in terme van ontoereikende getalle val en ' $n$ omvattende strategiese ingryping om die land se menslike gesondheidshulpbron krisis op te los, belemmer. Dit het aangedui dat die getalletekort maar slegs een fasset van 'n groter probleem uitmaak, wat onder andere die volgende insluit: die oneweredige verspeiding van menslike gesondheidshulpbronne, 'n fokus op ontoepaslike vaardighede in die opleiding van verpleegpersoneel, die behoud van personeel in die openbare gesondheidsektor, asook die konstant-veranderlike eise van die gesondheidsdienste. Verder was die uitdaging in Suid Afrika die opleiding en behoud van gesondheidsorgpersoneel met kennis en vaardighede wat tred hou met die veranderlike eise van die openbare gesondheidsdienste.

\section{Introduction}

International agencies support a health system strengthening agenda in developing countries within strategic initiatives to promote the integration of HIV and AIDS programmes into general health programmes (Pfeiffer, Montoya, Baptista, Karagianis, Pugas, Mde, et al. 2010; WHO 2005, 2007) and, more recently, to revitalise the principles and practice of primary health care (PHC) (Frenk 2009; Lawn et al. 2008; WHO 2010). Once facet of this agenda is to ensure an adequate number of appropriately skilled health care personnel to deliver services. Assessments to date have highlighted the shortage of personnel in many African countries. The general baseline is the projection of the World Health Organization (WHO) that there should be a minimum of 230 health professionals per 100000 people (WHO 2006a, 2006b).

The WHO's assessment revealed a critical shortage of health care personnel in $36(78 \%)$ of the countries in Africa, representing the majority (63\%) of all countries in the world where this is the case. However, it has become evident that shortage cannot mean simply insufficient numbers of health care personnel. The case of South Africa illustrates this issue. Firstly, the WHO's (2006a) assessment summarised below, shows that South Africa exceeded the minimum ratios of 20 medical practitioners and 120 nurses respectively per 100000 people (Table 1). Calculations for 2010 of the number of general practitioners (GPs) and specialists working in South Africa show that there are 17801 GPs and 9630 specialists (Econex 2010a). These figures imply a doctor to patient ratio of 62:100 000 people.

Secondly, a World Bank assessment that includes economic criteria, reported that South Africa, as a middle-income country, should have a general ratio of 180 doctors per 100000 people. However, the actual ratio is closer to what would be expected for a low-income country (50:100 000) and it is much lower than equivalent middle-income developing countries such as Mexico (198 per 100 000) and Brazil (185 per 100 000) (Econex 2010a).

Thirdly, local assessments of HRH in South Africa have highlighted the skewed distribution of human resources between the public and private health sectors and between rural and urban areas, and the changing demands on the public health services following the introduction and expansion of the national antiretroviral treatment (ART) programme in 2004 and integration of 
HIV and AIDS programmes into general health programmes (Bateman 2007; Breier 2009; Couper, De Cilliers \& Sondzaba 2005; Lehmann 2008; McIntyre \& Klugman 2003; Schneider et al. 2006; Sanders \& Lloyd 2009; Shishana et al. 2004; Van Rensburg et al. 2008).

In sum, South Africa has a shortage of health care personnel. The HRH for the Health Sector Strategy: 2012 and 2013-2016 and 2007 of the national Department of Health (DoH), duly acknowledges some aspects of previous local assessmentsbut of some concern, still emphasises the need broadly to employ more staff (DoH 2011).

\section{Objectives}

Our objective is to show why the HRH constraints in South Africa cannot be viewed primarily as insufficient numbers of health care personnel. To be clear, we do not deny that there is a numerical shortage of staff in the public health service. However, it is one facet of a broader HRH problem that includes inadequate harnessing of health professionals' skills and expertise, the production of inappropriate skills, particularly in the nursing care, and ongoing and high levels of staff attrition.

Our analysis is informed by the changing burden of disease and the changing demands on the health services. We refer to changes as a result of expansion of the national ART programme (more people in need of comprehensive care and continuum of care), health technology interventions (e.g. male circumcision) and innovations (e.g. integration of community home-based care $(\mathrm{CHBC})$ programmes into PHC services), and the changing needs of HIV patients (e.g. more demand for support services and less need for homebased care). Detailed discussion of these contextual factors is beyond the scope of this article, but they should be kept in mind as significant factors that should inform any strategy to resolve the HRH problem in this country.

\section{Research methods and design Methods}

This article is derived from an HRH situational assessment conducted in 2009 over a period of three months (George, Quinlan \& Reardon 2009) in relation to the HIV and AIDS national strategic plan (NSP) for 2007-2011, ${ }^{1}$ and updated following the publication of the HRH for the Health Sector Strategy: 2012 and 2013-2016 and 2017 in 2011. This was a desk-top review. Analysis was founded on the Day and Gray's (2008) typology of four imbalances for examining the shortage and the distribution of HRH in a health system, namely profession or speciality, geographic, institutional and service and demographic imbalances.

As Day and Gray (2008) warned, precise disaggregation of South Africa's HRH data according to this typology is difficult. We investigated anomalies in the large, yet fragmented, body of information, to try to resolve those difficulties. In turn, that 1.The report is in the public domain: http:// www.heard.org.za investigation led to re-appraisal of what was meant by the HRH shortage. Key referents included the NSP as well as past and current health and human resource policies and plans.

\section{Results}

\section{The numbers and distribution of professional staff}

Hamilton and Yau (2004) reported that $46 \%$ of the population lived in rural areas but, in the early 2000s, they were served by only $12 \%$ of the country's doctors and $19 \%$ of nurses. Four years later, Day and Gray (2008) reported that 30\% of the country's medical practitioners and $15.5 \%$ of pharmacists were employed in the public health sector but they served an estimated $85 \%$ of the population.

In the early 2000s all nine provinces had medical practitioner to people ratios that were higher than the WHO minimum

TABLE 1: Cross-country comparison of physician and nurse rations per 100000 population.

\begin{tabular}{lcc}
\hline Country & \multicolumn{2}{c}{ Ratio per 100 000 people } \\
\cline { 2 - 3 } & Medical practitioner & Nurse and midwifery \\
\hline Lesotho & 5 & 60 \\
Brazil & 185 & 290 \\
Mexico & 198 & 400 \\
Greece & 500 & 350 \\
South Africa & 55 & 383 \\
United States of America (USA) & 256 & 980 \\
Australia & 247 & 1090 \\
\hline
\end{tabular}

Source: Econex (2010b; 2010c).

TABLE 2: Ratio of medical practitioners per 100000 population across provinces, 2001, 2004 and 2010

\begin{tabular}{lccc}
\hline Province & \multicolumn{3}{c}{ Year } \\
\cline { 2 - 4 } & $\mathbf{2 0 0 1}$ & $\mathbf{2 0 0 4}$ & $\mathbf{2 0 1 0}$ \\
\hline Gauteng & 173 & 126 & 102 \\
Western Cape & 182 & 147 & 135 \\
KwaZulu-Natal & 70 & 52 & 53 \\
Free State & 69 & 54 & 55 \\
Northern Cape & 54 & 42 & 37 \\
Mpumalanga & 42 & 30 & 50 \\
Eastern Cape & 34 & 27 & 31 \\
North West & 30 & 23 & 20 \\
Limpopo & 21 & 18 & 17 \\
\hline
\end{tabular}

Sources: Econex (2010b); Hall and Erasmus (2003); HPCSA 2004 data cited in Breier and Wildschut (2006)

TABLE 3: Ratio of professional nurses per 100000 population across provinces, 2006 and 2008.

\begin{tabular}{lcc}
\hline Province & \multicolumn{2}{c}{ Year } \\
\cline { 2 - 3 } & $\mathbf{2 0 0 6}$ & $\mathbf{2 0 0 8}$ \\
\hline Gauteng & 565 & 529 \\
Western Cape & 543 & 512 \\
KwaZulu-Natal & 456 & 492 \\
Free State & 387 & 410 \\
Northern Cape & 370 & 339 \\
Mpumalanga & 286 & 290 \\
Eastern Cape & 289 & 328 \\
North West & 336 & 403 \\
Limpopo & 303 & 365 \\
\hline Total & 414 & 436 \\
\hline
\end{tabular}

Source: South African Nursing Council (SANC) $(2008,2009)$ 
TABLE 4: Percentage of vacant posts in public health sector for health professionals, medical practitioners, and professional nurses.

\begin{tabular}{|c|c|c|c|c|c|c|c|c|c|c|}
\hline \multirow[t]{2}{*}{ Year } & \multicolumn{10}{|c|}{ Percentage in South African provinces } \\
\hline & GP & WC & KZN & FS & NC & MP & EC & NW & LP & SA \\
\hline \multicolumn{11}{|c|}{ Posts vacant as health professional } \\
\hline 2002 & 47.4 & 34.7 & 35.6 & 48.9 & 45.2 & 38.6 & 51.6 & 50.5 & 30.1 & 42.5 \\
\hline 2003 & 31.9 & 13.8 & 24.5 & 40.7 & 27.3 & 67.4 & 28.4 & 33.0 & 13.4 & 31.1 \\
\hline 2005 & 26.7 & 8.1 & 29.6 & 40.5 & 35.1 & 43.9 & 26.6 & 23.1 & 15.8 & 27.2 \\
\hline 2006 & 24.2 & 16.9 & 32.4 & 40.4 & 37.8 & 43.1 & 32.6 & 23.1 & 16.4 & 29.0 \\
\hline 2007 & 32.8 & 18.7 & 35.6 & 41.9 & 41.8 & 42.5 & 33.3 & 41.9 & 20.0 & 33.3 \\
\hline 2008 & 28.1 & 23.3 & 33.3 & 50.7 & 36.3 & 37.6 & 48.0 & 11.6 & 42.1 & 35.7 \\
\hline \multicolumn{11}{|c|}{ Posts vacant as medical practitioner } \\
\hline 2006 & 20.9 & 12.6 & 34.3 & 33.6 & 53.4 & 38.5 & 36.1 & 29.9 & 26.8 & 29.9 \\
\hline 2007 & 27.4 & 14.8 & 39.5 & 35.0 & 51.1 & 41.8 & 32.7 & 42.8 & 31.6 & 34.1 \\
\hline 2008 & 29.4 & 17.4 & 36.7 & 33.8 & 60.2 & 51.3 & 40.1 & 21.3 & 35.4 & 34.4 \\
\hline \multicolumn{11}{|c|}{ Posts vacant as professional nurse } \\
\hline 2006 & 26.0 & 22.0 & 42.5 & 31.4 & 33.2 & 40.0 & 34.0 & 22.8 & 15.0 & 31.5 \\
\hline 2008 & 34.4 & 31.0 & 39.6 & 51.6 & 25.3 & 29.8 & 53.6 & 13.2 & 43.7 & 40.3 \\
\hline
\end{tabular}

Source: Health Systems Trust (2009).

EC, Eastern Cape;FS, Free State; GP, Gauteng; KZN, KwaZulu-Natal;LP, Limpopo; MP, Mpumalanga; NC, Northern Cape; NW, North West; WC, Western Cape; SA, South Africa.

of 20:100 000, which is due in part to the figures including those employed in both the private and public health sectors. However, the provinces with the country's major cities (Gauteng, Western Cape, Free State and KwaZuluNatal) where private sector facilities are concentrated, had a higher proportion of medical practitioners serving the population than the rural provinces (Eastern Cape, Limpopo, Mpumalanga, North West and the Northern Cape). The records indicate worsening of the medical practitioners to people ratio in the majority of the provinces across South Africa (Table 2).

For nurses, however the records present a different picture (Table 3). South Africa had more than the WHO minimum ratio of 120 nurses per 100000 people. The ratio generally improved in the mid-2000s, but there were still rural-urban disparities.

These contrasts are reflected in the Health Systems Trust's (2009) estimation that $35.7 \%$ of health professional posts were vacant in 2008..$^{2}$ An assessment in 2010 revealed high vacancy rates in Limpopo (68\%), Eastern Cape (59\%) and Free State (47\%) (Econex 2010b). However, the rates change over time (Table 4).

There was general improvement between 2002 and 2005, but deterioration thereafter, and marked variation between professions and provinces. For instance, the vacancy rates generally decreased in Gauteng and substantially in two rural provinces (Northern Cape and North West) but there was no corresponding decrease with regard to the professions of medical practitioner and professional nurse in Gauteng and medical practitioner in the Northern Cape. Using data from the government's Personnel and Salary Administration

2.Erasmus (2008), (cited in Breier, Wildshut \& Mgqolozana 2009) analysed vacancies advertised in the Sunday Times newspaper between April 2004 and March 2007. It found that nearly one third of the vacancies were for health professionals (17 479), of which the largest category of vacancies was for midwives and professional nurses

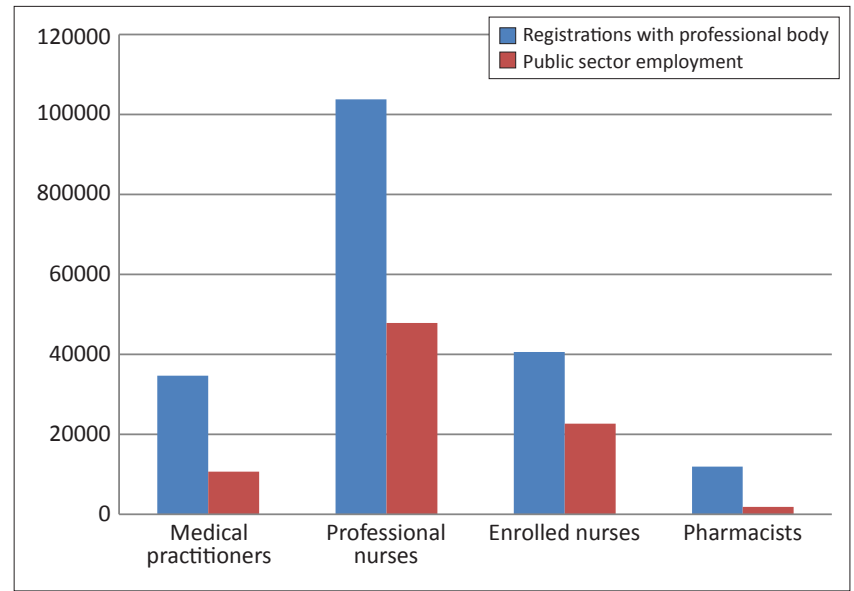

Source: Day and Gray (2008)

FIGURE 1: Number of HRH employed in public sector, 2007 and 2008

System (PERSAL), national vacancy rates for GPs, specialist doctors, and other health professionals for 2010 were calculated as $49 \%, 44 \%$, and $42.5 \%$ respectively. These figures show that there is a numerical shortage of staff in the public health services, but it is one facet of a broader HRH problem.

Since 2009, the skewed distribution of professional staff between the public and private sectors has been the focus of official attention because of the proposed National Health Insurance (NHI 2009) scheme which would see people being able to use private sector facilities irrespective of income level (Sanders n.d; NHI 2009). Indicators of the disparity are represented and derived from a comparison of numbers of professional staff registered with their respective professional bodies, and the numbers employed in the public sector in 2007 and 2008 (Figure 1).

However, the records also indicate general growth of professional registrations in the country during this decade (Table 5). The table includes different categories of nursing staff. Professional nurses have completed a four-year course 
TABLE 5: Growth in health professional registrations, 2002-2008.

\begin{tabular}{|c|c|c|c|c|c|c|c|c|c|}
\hline \multirow[t]{2}{*}{ Professional category } & \multicolumn{7}{|c|}{ Registrations occurring between 2002-2008 } & \multirow{2}{*}{$\begin{array}{l}\text { Change from } 2002 \text { to } \\
2007 \text { and } 2008 \text { in \% }\end{array}$} & \multirow{2}{*}{$\begin{array}{c}\text { Annual average } \\
\text { growth in \% }\end{array}$} \\
\hline & 2002 & 2003 & 2004 & 2005 & 2006 & 2007 & 2008 & & \\
\hline Medical practitioners & 29903 & 30578 & 31214 & 32198 & 33220 & 34324 & 34687 & 16.00 & 2.50 \\
\hline Professional nurses & 94948 & 96715 & 98490 & 99534 & 101295 & 103792 & - & 9.30 & 1.80 \\
\hline Staff nurses & 32495 & 33575 & 35266 & 37085 & 39305 & 40528 & - & 24.90 & 4.50 \\
\hline Nursing auxiliaries & 45426 & 47431 & 50703 & 54650 & 56314 & 59574 & - & 31.10 & 5.60 \\
\hline Pharmacists & - & 10629 & 10891 & 10824 & - & 11547 & - & 12.00 & 2.30 \\
\hline
\end{tabular}

Source: NHI 2009

*The registration numbers include a proportion of health professionals that are retired, out of the country, or inactive. The total number of practising health professionals is lower than the total registrations.

either a degree or diploma level. Staff nurses and auxiliary nurses are trained via two-year and one-year training programmes provided by public and private nursing colleges respectively (Subedar 2005). ${ }^{3}$

Day and Gray (2008) pointed out that the ratios of professional and staff nurses to people in the public health sector had worsened over time. The ratio with regard to professional nurses was 251:100 000 in 1994 but 116.6:100 000 in 2008 . With regard to staff nurses, the ratio was 59.7:100,000 in 2001 but 55.4:100 000 in 2008. Wildschut and Mgqolozana (2009) suggested that these different trends indicated inadequate harnessing of the skills and expertise that do exist. For example, they estimated, using South African Nursing Council (SANC) 2009 data, that $17.6 \%$ of the registered nurses were inactive at the time and most likely retired out of the profession or working overseas and also that $65 \%$ of professional nurses trained between 1997 and 2005 did not appear on the SANC register.

A difficulty for analysis is that key factors, relative lack of skills and their utilisation, tend to be combined in assessments to emphasise the problem as one of numerical shortage. For instance, Wildschut and Mgqolozana's (2009) analysis included three sources of information that combine these indicators. Firstly, the DoH's 2006 National Scarce Skills List suggested that the country was short of 14370 professional nurses (10 250 registered professional nurses and 4120 primary clinical nurses). ${ }^{4}$ Secondly, the DoH's Operational Plan for Comprehensive HIV and AIDS Care, Management, and Treatment (DoH 2003) noted the need for the appointment of an additional 13805 health care staff of whom 4393 should be nurses. Thirdly, the country's Health and Welfare Sector Education and Training Authority (HWSETA) Draft Sector Skills Plan 2006-2009 recorded that the country was short of 3480 appropriately trained and skilled nurses particularly in the staff nurse and nursing assistant categories. Africa Health Placements, an NGO that recruits doctors to work in rural areas, calculated in a different manner that half of the 2400 medical graduates in 2006 and 2007 would leave the country; that amongst the remaining 1200 doctors, 75\% would work

3.This article focuses on professional and staff nurses as a way to avoid the confusion that can arise from use of various terms to be found in the literature. We have followed the terminology used in the Nursing Act of 2003, which uses the term staff nurses in relation to enrolled nurses. It also uses the term auxiliary nurse, though other documents sometimes use the term nurse assistant.

4.A primary clinical nurse (PNC) refers to professional nurses (traditionally known as Primary Health Care Nurse) who have the additional post-basic qualification of
Diploma in Clinical Nursing Science, Health Assessment, Treatment and Care as Diploma in Clinical Nursing Science, Health Assessment,
recognised by the SANC. (Magobe, Beukes \& Müller 2010) in the private sector, leaving 300 to work in the public sector; and that amongst these 300 doctors, possibly 70 (2.9\% of the total graduate number) would work in a rural facility (Bateman 2007).

In summary, calculations by different agencies have used various indicators to make the point that there is a numerical shortage of health care personnel. Consequently, summations do vary. In our report (George et al. 2009) we estimated that 19277 professional nurse posts were vacant in 2008 based on a comparative analysis of the overall vacancy rate of $40.3 \%$ (Table 4) (Health Systems Trust 2009) and Day and Gray's (2008) assessment that there were 47834 professional nurses employed in the public sector in 2008.

We acknowledge that such summations are problematic in view of the variations in the deficit of staff between professions, provinces and health sectors. Notably, the indications of unequal distribution of staff between provinces as well as between the private and public sectors, suggest the significant challenge is generating and retaining an appropriate mix of skills and expertise in the health system. To illustrate, if there are approximately 140000 to 150000 professional nurses (Day \& Gray 2008) and 15-20\% are inactive (Wildschut \& Mgqolozana 2009), then there are 20000 to 30000 nurses who are not in the system; hence, the general figure of a shortage of 19000 nurses refers more to the inability of the health system to retain them and their skills, than to an absolute numerical lack of such skills. Taking the point further, the absence of $65 \%$ of professional nurses who were trained between 1997 and 2005, but who were not professionally registered (Wildschut \& Mgqolozana 2009), suggests that possibly another 18000 to 19000 nurses were never incorporated into the health system during this decade. ${ }^{5}$ Therefore, the record on the training of professional staff and on the attrition of staff from the health system deserves critical attention.

\section{Training of professional staff}

There are eight medical schools and 394 nursing education institutions in South Africa (SANC 2010). The statistical records indicate a steady output of trained staff and, overall, an increase in the numbers of different categories of staff trained each year (Table 6).

5.Erasmus (2008) records that the annual output of trained professional nurses increased from 2262 to 2371 between 1999 and 2008. We used an average of between 2000 and 2200 per year to derive an approximate total of 18000 to 19 000 nurses trained between 1997 and 2005 but who were or are not registered. 
The number of professional nurses graduating from fouryear programmes from nursing colleges and universities with nursing degrees or diplomas was 2494 in 2000 and 2638 in 2009 (SANC 2010). The number of staff nurses trained was 1919 in 2000 and 7493 in 2009, because of the establishment and expansion of nursing training at private colleges. ${ }^{6}$ For the same reasons, the number of nursing auxiliaries trained (via one-year programmes) was 1509 in 2000 and 5779 in 2009 (SANC 2010). The expansion of lower level nurse cadres established a platform for upgrading of skills over time via bridging programmes (Wildschut \& Mgqolozana 2009).

Nonetheless, these records obscure changes to the mix of skills and expertise amongst nurses. First, there has been no steady annual increase, but simply variable numbers each year, in the number of staff nurses who graduate from the bridging programmes as professional nurses: for example, 1991 in 2000 and 2475 in 2009 (SANC 2010). Consequently, the number of professional nurses emerging from four-year programmes (including nursing degrees and diplomas) and two-year bridging programmes each year has not increased significantly (4485 in 2000 and 5113 in 2009) when viewed in relation to the marked increase in the roles and responsibilities of nurses following the rapid expansion of the ART programme and current efforts to revitalise PHC services.

Secondly, the training system has set up a two-tier division of competence and authority between professional nurses. General health policy is to promote PHC facilities as 'one stop shops', meaning that they are supposed to provide a wide range of health services that includes, for example, delegation of some facets of HIV and AIDS prevention, counselling and treatment to nurses. However, only professional nurses that have had the necessary training are able to initiate HIVinfected patients onto ART (Cameron et al. 2012). In other words, South Africa is producing large numbers of nurses but it is not increasing, via training, the number and type of professional nurses who are capable of providing the PHC services required today (and who have the authority to do so).

Furthermore, there is an anomaly between the statistics on the numbers of nurses of all types that are being trained and the SANC (2009) report that a majority of all categories of nurses were over the age of 40 years old: $76 \%$ of professional nurses, $57 \%$ of staff nurses and $53 \%$ of nurse auxiliaries. ${ }^{7}$ The anomaly is that the investment in training professional nurses, staff nurses and bridging training for staff nurses during the last decade, has not resulted in at least a sizeable minority of nurses who are not yet 30 years old nor close to a majority of nurses under the age of 40 years old (assuming that the vast majority enter the profession between the ages of 18 and 20 years old). The intimation is that many newly

6.Private colleges produced 586 staff nurses in 1999 compared to 4366 in 2008 . Public institutions produced 2042 staff nurses in 1999 and 1788 in 2008 (SANC 2009).

7.The statistics do not show the proportion of professional nurses (i.e. those with training and authority to practice comprehensive nursing) in relation to staff nurses who have qualified as professional nurses but who are only qualified to practice general nursing.
TABLE 6: Total graduates produced by South Africa medical schools, 1996-2008.

\begin{tabular}{ll}
\hline Year & $\boldsymbol{n}$ \\
\hline 1996 & 1106 \\
1997 & 1233 \\
1998 & 1246 \\
1999 & 1087 \\
2000 & 1163 \\
2001 & 1079 \\
2002 & 1088 \\
2003 & 1207 \\
2004 & 1215 \\
2005 & 1330 \\
2006 & 1402 \\
2007 & 1108 \\
2008 & 1349 \\
\hline Total & 21613 \\
\hline
\end{tabular}

Source: National Department of Education (cited in Department of Health 2006); Eighty20 data cited in Econex, (2010b)

$n$, Given as number of medical graduates.

TABLE 7: International migration of South African professional health staff.

\begin{tabular}{lcccc}
\hline Health staff & \multicolumn{2}{c}{$\begin{array}{c}\text { Number practicing abroad } \\
\text { between 1998-2000 }\end{array}$} & $\begin{array}{c}\text { Total number } \\
\text { practicing abroad } \\
\text { in 2006 }\end{array}$ \\
\cline { 2 - 4 } & $\mathbf{1 9 9 8}$ & $\mathbf{1 9 9 9}$ & $\mathbf{2 0 0 0}$ & \\
\hline Medical practitioners & 105 & 83 & 105 & 8921 \\
Nurses and midwives & 133 & 117 & 147 & 6844 \\
Other health professionals & 110 & 101 & 126 & 7642 \\
\hline Total & 348 & 301 & 378 & 23407 \\
\hline
\end{tabular}

Source: Wadee \& Khan (2007).

trained nurses of all types are not being absorbed into the public health services and/or many, if not a majority, do not remain in these services. This intimation raises the issue of staff attrition.

\section{Staff Attrition}

There appear to be two primary causes of staff attrition: HIV and AIDS and migration. A nationwide survey of health workers in 2002 estimated that $15.7 \%$ of professional staff were HIV positive, that the highest rates (20\%) were amongst the 18-35 year olds; and, in terms of numbers, that 2745 nurses were likely to develop AIDS-related illnesses each year (Shisana et al. 2004). Connelly et al. (2007) reported similar findings with prevalence rates of $13.7 \%$ amongst certain nursing cadres. Therefore, it is probable that HIV infection is a significant factor behind the predominance of older ( $>40$ years old) nurses in public health services.

The emigration of large numbers of professional staff is a well-known phenomenon (Breier \& Wildschut 2006; Hamilton \& Yau 2004; Sanders \& Lloyd 2009). However, migration data is known to be inaccurate because there is no agency that collects standardised data on international flows of people disaggregated by occupation (Breier 2009; Clemens \& Pettersson 2008). Wadee and Khan (2007) summarised emigration trends amongst medical practitioners on the basis of DoH figures from 2001 (Table 7).

With regard to net losses, the WHO (2006b) estimated that approximately $37 \%$ of South African doctors and $7 \%$ of nurses had moved out of South Africa. Wildschut and 
Mgqolozana (2009) estimated a 1-2\% annual emigration rate amongst nurses which would amount to between 2128 and 4256 nurses. $^{8}$

\section{Discussion}

Staff attrition as a result of HIV and AIDS and migration compounds the problem of the unequal distribution of staff between the public and private sectors, as well as offsetting the training and investment in staff. However, it is not possible to measure how this attrition influences the variable growth and decreases in the distribution and registration of health care personnel because the data are so fragmented. For instance, the emigration of between 2000 and 4000 (presumably registered) nurses each year is significant in view of the estimated shortage of 19000 nurses. However, retention of health care personnel is perhaps the most critical challenge in view of the estimations that $15-20 \%$ of South Africa's professional nurses (20 000 to 30000 individuals) are inactive and another 18000 to 19000 were never registered (in the early 2000s). Likewise, the annual emigration of between 1000 and 1200 doctors (Mallaby 2004; Bateman 2007) represents a persistent loss of scarce high-level expertise, but the estimated annual recruitment of 900 graduates into the private sector represents failure to capitalise on the investment in training those doctors.

\section{Limitations of the study}

This article constitutes a desk-top review of relevant documents primarily pertaining to the training, distribution, vacancies, registrations and emigration of health care workers in South Africa to help assess the relative numerical shortage of health care workers in South Africa. It does not attempt to provide a detailed discussion of the reasons for the increase or decrease in health care worker numbers seen in each of these areas. Similarly, the review focused narrowly on cadres of nurses and medical doctors. Other categories of health professionals such as pharmacists, physiotherapists, dentists, occupational therapists and psychologists, crucial to the delivery of health care services, were not included. In terms of the methodology, the researchers included documents (government reports, academic literature etc.) that were electronically available over the internet; thus, information that was not available on the internet was not included in our discussions or calculations.

\section{Recommendations}

The DoH and proponents of the NHI should acknowledge that the shortage of health care personnel cannot be reduced to meaning insufficient numbers of health care personnel. Thinking in those terms inhibits, for example, consideration of the fact that South Africa has an abundance of nurses. The imperative is to:

- attract and retain the thousands of individuals who have been trained as nurses

8.Migration News (2008), citing a survey by the Southern African Migration Project (SAMP), reported half of South Africa's health professionals planned to emigrate (SAMP), reported half of South Africa's health professionals planned to emigrate
within the next five years, on the basis of 1700 responses from 29000 doctors, within the next five years, on the
nurses and other health workers.
- to train the type of professional nurses who have the skills and authority to manage and deliver the comprehensive PHC services

- to take into account, in training plans, the erosive effect of HIV and AIDS on the composition of the workforce of nurses

Likewise, the shortage of doctors is not primarily a numerical problem, but a function of failure to capitalise on the investment in training them. Even if the loss by emigration of half of the annual total of graduates cannot be curtailed, there are still approximately 1200 doctors produced each year who remain in the country. Therefore, if there are adequate incentives, within a few years there should be more than enough practitioners to achieve a sound ratio of doctors to that part of the population that is dependent on the public health services.

For proponents of the NHI, a short-sighted strategy is to increase the number of health care personnel indirectly by enjoining those in the private sector to provide services to the general public. It is a strategy to alleviate the pressure on health care personnel in the public health service, rather than to strengthen the health system as a whole.

\section{Conclusion}

The shortage of health care personnel refers primarily to inadequate production, harnessing and retention of appropriately skilled health care personnel. Furthermore, it should be seen in terms of a need for regular development of new skills and retention of expertise as a result of a changing burden of disease and, in relation to HIV and AIDS services, changing demands on health care personnel. Therefore, to see South Africa's HRH challenges as a problem of an inadequate number of staff is to focus on the symptoms of the problem.

Our assessment shows that there are significant variations with regard to the increase and decrease over time in the number and distribution of different categories of staff. These variations indicate that the country is reproducing the skills it needs but, in the context of HIV and AIDS and the need for comprehensive skills, not in the right proportions. Staff attrition and poor retention of the skills and expertise compound this problem. One effect is a shortage of staff. However, the substantive challenge is to harness effectively and retain the skills and expertise that exist and are being reproduced and importantly, in the context of a changing and high burden of disease, to ensure that the training of nurses produces the skills that are needed.

\section{Acknowledgements}

This assessment was possible through funding from The European Union.

\section{Competing interests}

The authors declare that they have no financial or personal relationship(s) which may have inappropriately influenced them in writing this article. 


\section{Authors' contribution}

G.G. (University of KwaZulu-Natal) conceptualised the study, interpreted the results and prepared the manuscript. C.R. (University of KwaZulu-Natal) made conceptual contributions, conducted the review and assisted in preparing the manuscript. T.Q. (University of KwaZulu-Natal) made conceptual contributions and revised the manuscript. J.F.A. made conceptual contributions and approved the manuscript.

\section{References}

Bateman, C., 2007, 'Slim pickings as 2008 health staff crisis looms', South African Medical Journal 97(11), 1020-1034. PMid:18250908.

Breier, M., 2009, 'Doctors', in J. Erasmus \& M. Breier, (eds.), Skills shortages in South Africa: Case studies of key professions, pp.113-131, HSRC Press, Cape Town.

Breier, M. \& Wildschut, A., 2006, Doctors in a divided society, The profession and education of medical practitioners in South Africa, HSRC Press, Cape Town. PMCid:1373667.

Breier, M., Wildshut, A. \& Mgqolozana, T., 2009, Nursing in a new era: The profession and education of nurses in South Africa, HSRC Press, Cape Town.

Cameron, D., Gerber, A., Mbatha, M., Mutyabule, J. \& Swart, H., 2012, 'Nurse initiation and maintenance of patients on antiretroviral therapy: Are nurses in primary care clinics initiating ART after attending NIMART training?' South African Medical Journal 102(2).

Clemens, M. \& Pettersson, G., 2008, 'New data on African health professionals abroad' Human Resources for Health 6(1), 1-11. http://dx.doi.org/10.1186/1478-4491-6-1

\section{PMid:18186916; PMCid:2254438.}

Connelly, D., Veriava, Y., Roberts, S., Tsotetsi, J., Jordan, A., DeSilva, E., et al., 2007, 'Prevalence of HIV infection and median CD4 counts among health care workers in South Africa', South African Medical Journal 97(2), 115-123. PMid:17404672.

Couper, I., De Villiers, M. \& Sondzaba, N., 2005, 'Human resources: District hospitals', in P. ljumba \& P. Barron (eds.), South African health review 2005, Health Systems Trust, Durban, viewed 14 September 2009, from http://www.hst.org.za/sahr

Day, C. \& Gray, A., 2008, 'Health and related indicators', in P. Barron \& J. Roma-Reardon (eds.), South African health review 2008, Health Systems Trust, Durban, viewed 14 September 2009, from http://www.hst.org.za/sahr

Department of Health 2003, 'Operational plan for comprehensive HIV and AIDS care, management and treatment for South Africa', viewed 04 October 2009, from http://www.info.gov.za/issues/hiv/careplan.htm

Department of Health 2006, A National Human Resources Plan for Health to provide skilled human resources for healthcare adequate to take care of all South Africans, viewed 17 August 2009, from http://www.doh.goz.za/docs/discuss-f.html

Department of Health 2011, HRH Strategy for the Health Sector: 2012/13 - 2016/17, Department of Health, Pretoria.

Econex, 2010a, 'Updated GP and specialist numbers for SA', Health Reform Note 7 October, 2010.

Econex, 2010b, 'The human resource supply constraint: The case of doctors', Health Reform Note 8, November, 2010.

Econex, 2010c, 'The human resource supply constraint: The case of Nurses', Health Reform Note 9, December, 2010.

Erasmus, S., 2008, 'Exodus of SA doctors looms', News 24: Press report.

Frenk, J., 2008, 'Reinventing primary health care: the need for systems integration', Lancet 374, 170-73. http://dx.doi.org/10.1016/S0140-6736(09)60693-0

George, G., Quinlan, T. \& Reardon, C., 2009, Human Resources for Health in South Africa: A needs and gaps analysis for HRH in South Africa, Health Economics and HIV/AIDS Research Division, University of KwaZulu-Natal.

Hall, E. \& Erasmus, J. 2003, Medical practitioners and nurses, in Human Resources Development Review 2003: Education, employment and skills in South Africa, pp.523-553, Cape Town, HSRC Press.

Hamilton, K. \& Yau, J., 2004,'The Global Tug-of-War for Health Care Workers', in HRH Global Resource Center, viewed 02 August 2009, from http://www. hrhresourcecenter.org/node/1264
Health Systems Trust 2009, 'Health statistics', viewed 05 August 2009, from http:// www.hst.org.za/healthstats

Lawn, J., Rohde, J., Rifkin, S., Were, M., Paul, V. \& Chopra, M., 2008, 'Alma-Ata 30 years on: Revolutionary, relevant, and time to revitalise', Lancet 2008(372), 917-922. http://dx.doi.org/10.1016/S0140-6736(08)61402-6

Lehmann, U., 2008, 'Strengthening human resources for primary health care', in P. Barron \& J. Roma-Reardon (eds.), South African health review 2008, Health Systems Trust, Durban, viewed 14 September 2009, from http://www.hst.org.za/ sahr.

Magobe, N.B.D., Beukes, S. \& Müller, A., 2010, 'Reasons for students' poor clinical competencies in the Primary Health Care: Clinical nursing, diagnosis treatment and care programme', Health SA Gesondheid 15(1). http://dx.doi.org/10.4102/ hsag.v15i1.525

Mallaby, S., 2004, How Africa subsidises US health care, Washington Post, 29 November, Washington, D.C.

McIntyre, D. \& Klugman, B., 2003, 'The human face of decentralisation and integration of health services: Experience from South Africa', Reproductive Health Matters 11(21), 108-119. http://dx.doi.org/10.1016/S0968-8080(03)02166-9

NHI 2009, 'National Health Insurance Policy Proposal', viewed 10 September 2009, from http://wikileaks.org/leak/anc-nhi-submission-nec-july2009.pdf

Pfeiffer, J., Montoya, P., Baptista, A.J., Karagianis, M., Pugas, Mde, M., et al., 2010, 'Integration of HIV/AIDS services into African primary health care: Lessons learned for health system strengthening in Mozambique - a case study', Journal of the International AIDS Society 13, 3, viewed 16 August 2009, from http://www. of the International AIDS Society 1
jiasociety.org/content/13/1/3

SANC 2009, Geographical and age distribution of nurses in South Africa, 06 August 2009, from http://www.sanc.co.za/stats/

SANC 2010, South African Nursing Council statistics, viewed 06 August 2009, from http://www.sanc.co.za/stats/

Sanders, D. n.d., 'National health insurance: Can it solve South Africa's health crisis?' in The Harold Wolpe Memorial Trust, viewed 06 August 2009, from http://www. wolpetrust.org.za/dialogue2009/presentation

Sanders, D. \& Lloyd, B., 2009, 'Major and focussed investment in health personnel is needed to solve the Health Care Crisis', In Amandla!, viewed 14 September 2009 from http://www.amandlapublishers.co.za/special-features/the-nhi-debate?start=15

Schneider, H., Blaauw, D., Gilson, L., Chabikuli, N. \& Goudge, J., 2006, 'Health Systems and Access to Antiretroviral Drugs for HIV in Southern Africa: Service Delivery and Human Resources Challenges', Reproductive Health Matters 14, (27), 12-23. http://dx.doi.org/10.1016/S0968-8080(06)27232-X

Shishana, O., Hall, E., Maluleke, R., Chauveau, J. \& Schwabe, C., 2004, 'HIV/AIDS prevalence among South African health workers', South African Medical Journal 94 (10), 846-850.

Subedar, H., 2005, 'The nursing profession: Production of nurses and proposed scope of practise', in P. Ijumba \& P. Barron (eds.), South African health review 2005 , Durban, Health Systems Trust, viewed 14 September 2009, from http://www.hst. org.za/sahr

Van Rensburg, D., Steyn, F., Schneider, H. \& Loffstadt, L., 2008, 'Human resource development and antiretroviral treatment in Free State province, South Africa', Human Resources for Health 6(15). PMid:18662390; PMCid:2531133.

Wadee, H. \& Khan, F., 2007, 'Human resources for health', in S. Harrison, R. Bhana \& A. Ntuli (eds.), South African health review, 2007, Durban, Health Systems Trust, viewed 14 September 2009, from http://www.hst.org.za/sahr

Wildschut, A. \& Mgqolozana, T., 2009, 'Nurses', in J. Erasmus \& M. Breier (eds.), Skills shortage in South Africa: Case studies of key professions, HSRC Press, Cape Town.

WHO 2005, Stage is set for a polio-free world, Polio News, 25, viewed 11 September 2009, from

http://www.polioeradication.org/content/polionews/PolioNews25.pdf

WHO 2006a, 'The World Health Report 2006: Working together for health', Geneva, World Health Organisation, viewed 10 August 2009, from http://www.who.int/ whr/2006/en/

WHO 2006b, 'Taking stock: Health worker shortages and the response to AIDS', viewed 10 August 2009, from http://www.who.int/hiv/pub/advocacy/ttr/en/index.html

WHO 2007, 'The Global Fund expands its role', Bulletin of the World Health Organisation 85, 742-743. PMid:18038053; PMCid:2636497.

WHO 2010, 'Framework for the implementation of the Ougadougo declaration on primary health care and health systems in Africa', World Health Organisation Regional Office, Brazzaville. 